\title{
Family and non-family women on the board of directors: Effects on corporate citizenship behavior in family-controlled fashion firms
}

\begin{abstract}
Drawing on self-construal theory and the family business literature, we offer theory and evidence on how the presence of women, either family members or not, on the board of directors of family firms affects firm engagement in corporate citizenship behavior. In examining corporate citizenship behavior, we argue that it is important to distinguish between corporate social responsibility and philanthropy as well as between family and non-family women on the board of directors. Using data from the population of 63 family-controlled firms in the global ranking of the top-100 fashion firms, we find support for our hypotheses: female directors are beneficial for corporate social responsibility engagement only if they are not members of the controlling family, while they are beneficial for philanthropic engagement only if they are members of the controlling family.
\end{abstract}

Keywords: Corporate citizenship; Board of directors; Family business; Women; Corporate social responsibility; Philanthropy.

\section{ACCEPTED FOR PUBLICATION IN \\ JOURNAL OF CLEANER PRODUCTION}

214 (2019), 41-51

Suggested reference: Campopiano, G., Rinaldi, F. R., Sciascia, S., \& De Massis, A. (2019). Family and nonfamily women on the board of directors: Effects on corporate citizenship behavior in family-controlled fashion firms. Journal of Cleaner Production, 214, 41-51. 


\section{Introduction}

Firm engagement in social issues is a key pillar of sustainability (Seuring and Gold, 2013; Waage et al., 2005; Yawar and Seuring, 2018), and permeates the economic landscape of several industries and countries (Eberhardt-Toth, 2017), benefitting stakeholders and society, without detrimental effects on firm performance (Brammer and Millington, 2008). Indeed, firms that commit to addressing social issues and thus contribute to the community with socially responsible and philanthropic initiatives are acknowledged as good corporate citizens (Gardberg and Fombrun, 2006). Corporate citizenship induces the firm to behave responsibly in response to stakeholder claims (Pacheco et al., 2018), in line with the changing social context that challenges firms to redefine their core business toward sustainable business models (Ritala et al., 2018), taking into account employees as well as external stakeholders (Loorbach and Wijsman, 2013).

Prior literature posits that board directors play a relevant role in driving socially-oriented principles and engaging their firm in social initiatives (e.g., Cuadrado-Ballesteros et al., 2015; Godos-Díez et al., 2011; Huang, 2013; Jo and Harjoto, 2012; Webb, 2004). A number of studies focus on the role of women on the board of directors (Bear et al., 2010; Buil-Fabregà et al., 2017; del Mar Alonso-Almeida et al., 2015; Fernandez-Feijoo et al., 2014; Nadeem et al., 2017; Setó-Pamies, 2015; Webb, 2004), in view of their increasing presence in business (Robinson and Stubberud, 2012) and especially on boards of directors (Seierstad et al., 2017). Moreover, the family business context is a relevant domain to investigate these issues (Cuadrado-Ballesteros et al., 2015; Martínez-Ferrero et al., 2016; RodríguezAriza et al., 2017). Indeed, family firms are the most ubiquitous form of business organization in any world economy (La Porta et al., 1999), and the appointment of family versus non-family directors is a key issue in this type of firm (Bammens et al., 2011; Sciascia et al., 2013; Voordeckers et al., 2007). Nevertheless, only scant research considers the difference between family and non-family women directors (Rodríguez-Ariza et al., 2017; Rubino et al., 2017). As such, and considering the ongoing debate on the role of women in the family business context (e.g., Campopiano et al., 2017), to our best knowledge this is the first study distinguishing between family and non-family female directors specifically in family firms. Accordingly, this study aims to advance our understanding of whether 
family and non-family women on the boards of directors affect family firm corporate citizenship behavior.

We build on previous studies relying on self-construal theory (Markus and Kitayama, 1991) to investigate the effects of women on boards of directors on corporate citizenship behavior. This theory suggests that women are characterized by interdependent self-construal, and thus behave differently to men (e.g., Peake et al., 2017). In addition, we deem it important to distinguish those with whom women are interdependent, as family women prioritize family interests while non-family women emphasize firm interests. Accordingly, we hypothesize that family and non-family female directors differently shape corporate citizenship behavior, which may predominantly benefit either the family or the business. Specifically, we examine two behaviors related to corporate citizenship: corporate social responsibility (hereafter, CSR) and philanthropy (e.g., Schwartz and Carroll, 2003). The former is defined as "the voluntary integration, by companies, of social and environmental concerns in their commercial operations and in their relationships with interested parties" (Ciliberti et al., 2008; European Commission, 2001, p. 7). This entails that firms embrace CSR to address specific issues that can benefit salient corporate stakeholders (Epstein, 1987; Vermeulen and Witjes, 2016; Wang and Sarkis, 2017). Instead, philanthropy refers to the discretionary wealth transfer of net income to stakeholders (Carroll, 1991; Windsor, 2006), financing initiatives that are not related to the core functions of the business, such as building museums, funding performances, and art exhibitions, and providing fellowships to graduate students (Hutchins and Sutherland, 2008). In particular, we embrace the extended view of corporate citizenship that encompasses responsibility toward social and environmental issues, especially regarding the challenges firm face in global supply chains, along with firm philanthropic endeavors (Ritala et al., 2018).

We test our hypotheses using data collected from the population of 63 family-controlled firms in the global ranking of the top-100 fashion firms. The findings support our hypotheses and show that nonfamily women on the board of directors are beneficial for CSR engagement, while family women on the board of directors do not significantly influence CSR engagement. Conversely, female directors are beneficial for philanthropic engagement only if they are members of the controlling family. 
These findings contribute to understanding the role of women in the corporate citizenship, family business, and corporate governance fields. First, we offer new reflections on the individual-level antecedents of corporate citizenship, looking at both CSR and philanthropy (O'Riordan and Fairbrass, 2008), showing that female directors have a different propensity to engage in social initiatives depending on their membership of the family system. Second, we contribute to the family business literature not only by shedding new light on the factors affecting CSR and philanthropy in these firms (e.g., Van Gils et al., 2014), but also advancing the debate on the role of women in the family firm context (Jimenez, 2009; Nelson and Constantinidis, 2017). As such, our study enriches existing research at the crossroads of family business and corporate citizenship (e.g., Martínez-Ferrero et al., 2016), pointing to the importance of considering the governance archetype of a business organization as a key antecedent of its corporate citizenship behavior. Moreover, corporate governance studies, especially those focusing on the consequences of gender diversity (Terjesen et al., 2016; Terjesen et al., 2009), will benefit from our study, as we highlight that the effects of female directors in the family firm context depend on their family membership. Last, we offer theoretical implications for self-construal theory. It is not enough to distinguish between independent and interdependent self-construal, as individuals might "define and make meaning of the self" (Cross et al., 2011, p. 143) according to other sources of diversity, such as membership of the family system.

In the remainder of this paper, we review the literature on female directors and corporate citizenship behavior, and present our theoretical perspective, hypotheses, methodology, and results, followed by a discussion on the implications and limitations of our study.

\section{Literature review}

Corporate citizenship has found fertile ground in different research streams. This topic has increasingly garnered interest at the interface of family business research and studies on female directors. We therefore first review the literature on family business engagement in corporate citizenship and then the relevant studies on the effects of female directors on corporate citizenship behavior, highlighting the gap at the interface of these literature streams. 


\subsection{Family business and corporate citizenship behavior}

Corporate citizenship encompasses corporate social responsibility and philanthropy (Ritala et al., 2018; Seaman, 2017). In the specific field of family business, research on CSR and philanthropy is still in its infancy, as evidenced by some editorials and review articles on this topic (e.g., Feliu and Botero, 2016; Seaman, 2017; Van Gils et al., 2014). Considering the differences between family and non-family firms, Dyer and Whetten (2006) find that compared to non-family businesses, family firms pay greater attention to social responsibility issues to avoid social concerns for two main reasons. First, family members might agree on the shared intent to treat their firm as an extension of their personal commitment to do well and do good as members of society. Second, family members may be afraid that

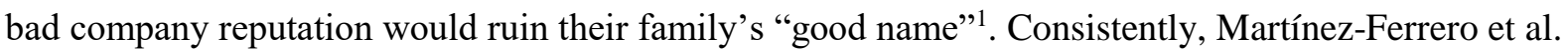
(2016) show that compared to non-family firms, family ownership acts as a mechanism decreasing the use of CSR as an entrenchment strategy of managers. Conversely, Labelle et al. (2018) find lower engagement in CSR in family firms with respect to their non-family counterparts, while Cruz et al. (2014) find that family firms place greater emphasis on external rather than internal stakeholders. As regards environmental impact, according to Sharma and Sharma (2011), family involvement is correlated with greater intentions to pursue environmentally friendly practices, an effect corroborated by the absence of relationship conflicts within the dominant coalition. This contribution echoes the findings of Craig and Dibrell (2006) who suggest that family firms facilitate environmentally friendly policies associated with improved firm innovation and greater financial performance than non-family businesses.

Beyond environmental protection, Campopiano and De Massis (2015) highlight the higher disclosure of philanthropy in family firms than in non-family firms. Narrowing the focus to corporate foundations, Lungeanu and Ward (2012) find that family foundations focus more on grantmaking than non-family foundations. Laguir et al. (2016) identify the family's greater involvement in the community as a driver of higher engagement in social initiatives, showing higher levels of warmth, integrity, and zeal than their non-family peers (Payne et al., 2011). Indeed, family businesses adopt a more relational

\footnotetext{
${ }^{1}$ This is consistent with the socioemotional wealth literature (e.g., Gómez-Mejía et al., 2007; Kotlar et al., 2017) arguing that growing the family's reputation is a key goal driving family firm behavior.
} 
orientation toward the community and employees, showing higher levels of corporate social performance than their non-family counterparts (Bingham et al., 2011).

Research on CSR and philanthropy in family firms also sheds light on the heterogeneity of family firms where values (e.g. identification and commitment) can differ across family firms (Marques et al., 2014). Attention to social issues depends on the family's broad versus narrow view of such issues (Déniz Déniz and Cabrera Suárez, 2005), and on the time the owning family has spent living and working in the community (Peake et al., 2017). Moreover, several studies consider the role of family involvement and socioemotional wealth as drivers of corporate citizenship behaviors. The extent of the family's involvement in ownership is found to be positively associated with diversity-, employee-, environment- and product-related aspects of CSR, while negatively affecting community-related CSR, suggesting that family firms can behave responsibly and irresponsibly at the same time (Block and Wagner, 2014). Further, Labelle et al. (2018) suggest that economic and socioemotional wealth are used as competing reference points affecting the CSR behavior of family firms at different levels of family involvement, finding support for a curvilinear relationship between family control and corporate social performance. Family involvement in the business has also been studied in relation to environmental and philanthropic engagement. As regards the former, alternative configurations of ownership and governance can catalyze the environmental social performance of family firms (Samara et al., 2018). Concerning the latter, family involvement in ownership is positively related to charitable donations, unless the next generation is unwilling to take over the business (Dou et al., 2014). Instead, the interaction of family involvement in ownership and management can dampen the positive effect of family control on philanthropic engagement (Campopiano et al., 2014).

Despite the ongoing debate, the focus on gender in studies on corporate citizenship behavior of family firms is still very limited, as illustrated in the next section.

\subsection{Female directors and corporate citizenship behavior}

Directors have a key role in promoting CSR initiatives (Fernandez-Feijoo et al., 2014; Jamali et al., 2008), which is often ascribed as one of their goals (Elkington, 2006). The presence of female directors, initially discussed in board diversity studies (e.g., Galbreath, 2011; Ibrahim and Angelidis, 
2011; Zhang et al., 2013), would seem to be beneficial for CSR and philanthropic engagement. Women's participative style and open communication within the board increases the board's sensitivity toward socially responsible activities, fostering a broader perspective of stakeholder needs (Bear et al., 2010; Rodríguez-Ariza et al., 2017). Indeed, women are often appointed as directors for their sensitivity, and firms with women on the board are acknowledged as more philanthropic (Burgess and Tharenou, 2002). Subsequent studies on philanthropic engagement show that the inclusion of women on the board is positively related to philanthropic initiatives, especially in community services and the arts (Williams, 2003).

However, despite the preponderance of family-controlled firms, evidence suggests that there are differences between female and male managers in moderating the relationship between the time spent within a community and family firm engagement in CSR (Peake et al., 2017). Considering the presence of female directors, while a high proportion of women on the board of directors is positively related to CSR disclosure in family firms (Cuadrado-Ballesteros et al., 2015), the comparison between family and non-family firms shows that the presence of female directors affects CSR in family firms to a lesser extent than in non-family firms (Rodríguez-Ariza et al., 2017). However, to our best knowledge, no studies explicitly consider the family membership of female directors as a potentially significant driver of corporate citizenship behavior. More importantly, given the unique characteristics of family firms, distinguishing between family and non-family female directors and their effect on CSR and philanthropic engagement can advance the debate on women in family business with relevant insights on both CSR and philanthropy. This might be especially relevant considering that women have to fulfil with their traditional roles as family nurturers and caretakers while simultaneously holding the reins of the business. This leads them to meld family and business responsibilities (Cruz et al., 2012) so that as business leaders, women are also acknowledged as nurturers of family unity and the continuity of the family business (Poza and Messer, 2001). To disentangle this issue, the following section introduces self-construal theory, and develops our hypotheses on the effect of female family directors on two aspects of corporate citizenship behavior, namely, CSR and philanthropic engagement. 


\section{Theoretical background and hypotheses}

\subsection{Self-construal theory}

Stemming from psychology, self-construal theory describes individual differences in the structure of the self (Baumeister and Sommer, 1997; Cross and Madson, 1997; Markus and Kitayama, 1991). In particular, "self-construal refers to how individuals define and make meaning of the self" (Cross et al., 2011, p. 143). Although this theoretical perspective has its roots in observing the cultural differences between the American and Japanese populace (Markus and Kitayama, 1991), it also suggests that significant differences exist between men and women: men are characterized by independent selfconstrual whereas women are characterized by interdependent self-construal (Cross and Madson, 1997). Women's interdependent self-construal is also referred to as relational due to the close connections characterizing their relationships with others (Cross et al., 2000), also described as dyadic (Baumeister and Sommer, 1997). Self-construal has relevant implications in terms of cognition, emotion, and motivation: individuals with interdependent self-construal have cognitive representations of the self that incorporate their social context, are more likely to be empathetic, expressing or experiencing others' emotions, and more likely to be motivated to pursue goals fulfilling their roles within important relationships (Cross et al., 2011).

Self-construal also affects the way individuals enhance, estimate, and evaluate themselves. Although in Western cultures, self-enhancement, self-esteem, and self-evaluation are based on demonstrating one's uniqueness and autonomy, there are differences between men and women whereby the latter's "positive feelings about the self should in some part derive from the development and maintenance of close relationships and from participation in the well-being of close others" (Cross and Madson, 1997, p. 11). In terms of corporate citizenship behavior implications, women are more likely to respond to the needs and claims of close others, and negotiate the demands of important roles, thus having greater sensitivity to the external constraints that influence their behavior (Cross and Madson, 1997). Therefore, this theory offers arguments to understand to what extent the attributes of interdependent self-construal characterizing women may affect their decision-making process in relation to engaging in CSR and philanthropic initiatives. 


\subsection{Hypotheses}

Philanthropic and CSR engagement can have different effects on the family's and the business' reputation, although both are considered instances of corporate citizenship behavior (Seaman, 2017). Philanthropy does not usually relate to core business activities (Porter and Kramer, 2002), and is therefore more likely to benefit the family's reputation, especially within the community where the family business is embedded, ensuring the visibility, social image, and social network of family members (e.g., Pan et al., 2018). CSR engagement, instead, often implies implementing social initiatives in line with core business activities, therefore mostly benefitting the business' reputation and its legitimacy in the eyes of various stakeholders (e.g., Block and Wagner, 2014).

As regards the role of female family directors, their interdependent self-construal, which leads them to nurture and care more about close relationships, can influence female family directors to behave differently when it comes to philanthropy. The discretionary nature of these initiatives, differently from CSR engagement, does not usually lead to a strategic return in terms of economic, legal, and ethical responsibilities. Considering instead that family members tend to be proud of their business, and are willing to enhance its reputation by contributing to the local community (Litz and Stewart, 2000), they may decide to engage in philanthropy. Taking care of the interests of family stakeholders and aiming to build a sustainable business across generations (Zellweger and Nason, 2008), family members may regard firm philanthropy as a means of being better stewards in their community (Campopiano et al., 2014). This holds especially for women, whose behavior is driven by their need to do their best for close members, reflected in both the local community's wellbeing and the family's reputation. Therefore, the distinctive traits of female leadership style are strengthened by women's perceptions of the reputational concerns related to the family, thus leading to higher engagement in philanthropy. Accordingly, we propose the following hypothesis.

H1. In family firms, women directors are beneficial for philanthropic engagement only if they are members of the controlling family.

On the other hand, concerning engagement in CSR, we agree with prior studies suggesting that women focus on relationships more than on economic and financial results (Frishkoff and Brown, 
1993). Therefore, once appointed as board directors, they may leverage their interdependent selfconstrual when engaging their business in CSR (Peake et al., 2017). However, this perspective enlightens only half the story: the family status of female family members helps explain why family firms are heterogeneous in their commitment to behave in a socially responsible way. Since CSR mainly concerns social initiatives related to the core business, e.g. supporting a sustainable supply chain (Ciliberti et al., 2008), the interest of directors mainly revolves around creating and maintaining the business reputation. Therefore, non-family female directors are more likely to encourage social initiatives toward CSR. With respect to their family counterparts who mostly rely on a personal network, non-family female members might leverage a broader network (Greve and Salaff, 2003). Moreover, they can benefit from previous experiences outside the current firm, and are thus more likely to direct their caring and nurturing attitude toward CSR to benefit the firm's reputation (e.g., CuadradoBallesteros et al., 2015). In line with the foregoing, we formally state:

H2. In family firms, women directors are beneficial for CSR engagement only if they are not members of the controlling family

\section{Methods and results}

\subsection{Empirical context}

To test our hypotheses, we used a unique dataset constructed between May 2014 and May 2015 (referring to the year 2013) constituted of the largest 100 international fashion firms by turnover according to Orbis (Bureau van Dijk's leading database of public and private international companies). By "fashion firms" we mean companies producing apparel, bags, and shoes.

We focused on the largest firms since they have considerably more stakeholders than small- and medium-sized firms, are acknowledged as having a greater social impact and a number of traits that foster CSR and philanthropy communication and reporting (Baumann-Pauly et al., 2013; Campopiano and De Massis, 2015). Overall, these 100 firms account for almost one third of total retail sales in the industry (Statista, 2013).

We chose to focus on the fashion industry not only because it is traditionally dominated by family businesses, but also because social issues are particularly relevant (Battaglia et al., 2014; De Brito et 
al., 2008; Kozlowski et al., 2012). For example, the International Labour Organization estimates that 170 million children are engaged in child labor in the fashion industry, since a substantial part of the supply chain requires low-skilled labor (The Guardian, 2016). Global scandals, such as the collapse of the Rana Plaza building in Bangladesh in April 2013, have raised attention to the lack of worker safety, especially for fourth tier sub-contractors working for global mass market retailers (The Guardian, 2015). Health and environmental issues in the fashion industry are considerable, including the intensive use of chemicals for dyes (De Brito et al., 2008), the huge amount of water and pesticides used in cotton cultivation (World Health Organization, 2016), and significant carbon emissions. According to Forbes (2015), the fashion industry is one of the largest industrial polluters, second only to oil. This is therefore a context where addressing social issues is particularly pressing. Further, research has shown that increasing attention is devoted to the establishment of a sustainable supply chain (Jia et al., 2018; Moretto et al., 2018; Spence and Bourlakis, 2009) and the introduction of green products in luxury segments of the industry (De Angelis et al., 2017).

In line with the components-of-involvement approach (Chrisman et al., 2005; Chua et al., 1999), we identified family-controlled firms by examining the level of family involvement in ownership and management. Indeed, these are the most adopted criteria to identify family firms (see HernándezLinares et al. (2018) for a rigorous bibliometric analysis of the family business definition). We collected data on family involvement in ownership and management via Orbis, company reports, and Bloomberg.com. Following Cascino et al. (2010), and Graves and Thomas (2006), we adopted a 50\% threshold for family involvement in ownership to ensure family control. We selected this prudent threshold because the dataset may include both listed and non-listed firms. In terms of family involvement in management, we adopted a threshold of 2 family members to ensure that lone-founder firms were excluded from the dataset (Miller et al., 2007).

Of the initial 100 fashion firms, we focused on the entire population of 63 family-controlled firms, representing our final dataset. This number of observations is similar to that used in other CSR (Dissanayake et al., 2016) and cleaner production (Liu and Gao, 2016) studies. These 63 companies are on average 52 years old, 44 percent are listed, with average revenues of $€ 820$ Mio. Concerning their geographic location, 52 percent have their headquarters in Italy, 18 percent are in the US, 14 percent in 
France, 10 percent in North European Countries (Denmark, Finland, Germany, Sweden), 3 percent in Spain, and 3 percent in Japan. Concerning their governance, 66 percent have a family CEO (although only 5 are women), the average board size is 7.8 , with female directors accounting for 22.2 percent.

\subsection{Variables}

We measured our dependent variables, namely, CSR and philanthropic engagement, taking into account the complex way of managing social issues in the fashion industry, which is characterized by high competition (Battaglia et al., 2014), strong environmental impact along the entire supply chain (De Brito et al., 2008), and brand reputation that each firm has to build and maintain in the eyes of customers and stakeholders who increasingly value CSR (De Angelis et al., 2017; Joergens, 2006). We collected the data by consulting the annual CSR/sustainability reports of each company (year 2013) and the company websites when ad-hoc reports were unavailable or when information on CSR in the annual reports was lacking. From these data sources, we identified the main CSR items in relation to the core activities of the value chain. As regards philanthropy, we measured the initiatives related to the community and to charity in general. We identified the items after consulting industry experts, such as members of the research center of Sistema Moda Italia, the leading national association representing Italian textile and clothing firms. Table 1 presents all the items considered.

Table 1

Indicators for CSR and philanthropic engagement, and related items.

\begin{tabular}{|c|c|}
\hline CSR engagement & Items (activities in place) \\
\hline Sourcing (12 items) & $\begin{array}{l}\text { - Reduction of hazardous materials/ chemicals } \\
\text { - Traceability of materials }\end{array}$ \\
\hline Cronbach's $\alpha: 0.852$ & $\begin{array}{l}\text { - Purchasing from firms adhering to Better Cotton Initiative } \\
\text { - Sustainable Apparel Coalition Membership } \\
\text { - Use of recycled materials } \\
\text { - Use of organic/sustainable materials } \\
\text { - Certification SA8000 } \\
\text { - Ban on materials coming from animals } \\
\text { - Protection of Biodiversity } \\
\text { - Textile Exchange Membership } \\
\text { - Availability of a supplier code of conduct } \\
\text { - Audits on suppliers }\end{array}$ \\
\hline Production (8 items) & $\begin{array}{l}\text { - Initiatives to improve sustainability of production facilities } \\
\text { - Initiatives to improve sustainability of logistics }\end{array}$ \\
\hline Cronbach's $\alpha: 0.757$ & $\begin{array}{l}\text { - Fair wage programs } \\
\text { - Adoption of a Code of Ethics } \\
\text { - Auditing on factories } \\
\text { - Local Production } \\
\text { - Safeguard of traditional craftsmanship } \\
\text { - Absence of sandblasting }\end{array}$ \\
\hline
\end{tabular}




\begin{tabular}{ll} 
Retail (12 items) & - Ethical Trading Initiative \\
Cronbach's $\alpha$ : 0.841 & - LEED certification/ BREEAM \\
& - Special collections realized with sustainable materials \\
& - Offsetting Co2 emissions \\
& - Water saving programs for stores \\
& - Waste reduction programs for stores \\
& - ISO14001 Certification \\
& - Programs value chain transparency \\
& - LED lighting system \\
& - Water efficiency initiatives for stores \\
& - Bring back programs \\
& - Use of renewable energy sources in the stores \\
& Items (activities in place) \\
\hline Philanthropic engagement & - Programs for sustaining the local community \\
& - Programs for sustaining local culture \\
& - Presence of a Foundation \\
& - Collaboration with NGOs/Associations \\
& - Charity projects to sustain the environment \\
Cronbach's $\alpha: 0.759$ & - Charity projects to sustain social initiatives \\
& - Donations \\
\hline &
\end{tabular}

CSR in the fashion industry can manifest in different areas along the value chain, and we hence constructed three specific indicators, i.e. CSR in sourcing, CSR in production, and CSR in retail. Thereafter, we constructed the indicator referring to philanthropic projects. Each of these four indicators was built as the mean of different items (see Table 1) representing micro-activities developed within the four areas (e.g. CSR in sourcing relies on the following items: use of recycled materials, use of organic/sustainable materials, SA8000 certification). Each item is a dummy variable equal to 1 if the firm is active in that micro-activity. The items composing the three indicators showed internal consistency (Cronbach's alpha equal to 0.852 for CSR in sourcing, 0.757 for CSR in production, and 0.841 for CSR in retail). We then calculated CSR engagement as the average of the three indicators regarding sourcing, production, and retail, thus representing a continuous variable ranging between 0 and 1 . We instead calculated philanthropic engagement as the average of the related items (Cronbach's alpha equal to 0.759 ), hence also a continuous variable ranging from 0 to 1.

The independent variables include two measures referring to board composition: family women on the board, measured as the percentage of directors who are female and members of the controlling family (mean $=7.1 \%$ ), and non-family women on the board, measured as the percentage of directors who are female and not members of the controlling family (mean $=15.1 \%$ ). Although these figures seem quite low, the percentage of women on boards is much higher than that reported in previous studies on women directors in family firms (Bianco et al., 2015; Rodríguez-Ariza et al., 2017). 
We also controlled for firm size measured by sales in 2012 (logarithm transformation), as large firms have a greater need and ability to engage in CSR (e.g. Baumann-Pauly et al., 2013). We controlled for past performance in accordance with studies suggesting that positive results in the past allow the necessary resources to invest in CSR and philanthropic initiatives (e.g. Cochran and Wood, 1984). In particular, we measured the change in turnover from 2009 to 2011. Furthermore, we included the number of directors on the board, as board size is considered important for CSR and philanthropic engagement (e.g. Frias-Aceituno et al., 2013). Finally, we controlled for the cultural context of the country where the firm was founded, as this may also influence CSR (Ringov and Zollo, 2007). In particular, we controlled for power distance, which reflects the degree to which the members of a society believe that power should be concentrated in the hands of leaders who should be obeyed without question, thus negatively affecting CSR and philanthropic engagement (Peng et al., 2014). Data on power distance are publicly available on the Hofstede Insights website ${ }^{2}$ reporting information on culture at the country level as continuous variables ranging between 0 and 100 .

\subsection{Analysis}

Table 2 shows the descriptive statistics and correlations. We developed two regression models to test our hypotheses (see Table 3). The variance inflation factors (VIFs) show that multicollinearity is not a concern, as all VIF coefficients are lower than 5 (Hamilton, 2012). In each of the two models, we introduced the control variables (step 1) and the two board-related variables (step 2).

Table 2

Descriptive statistics and correlations.

\begin{tabular}{|c|c|c|c|c|c|c|c|c|c|c|c|}
\hline & Mean & S.D. & Min & $\operatorname{Max}$ & 1. & 2. & 3. & 4. & 5. & 6. & 7. \\
\hline 1. Power distance & 49.667 & 10.482 & 18 & 68 & & & & & & & \\
\hline $\begin{array}{l}\text { 2. Firm size (log } \\
\text { transformation) }\end{array}$ & 20.524 & 1.517 & 16.816 & 24.096 & -0.005 & & & & & & \\
\hline 3. Past performance & 0.329 & 0.355 & -0.694 & 1.585 & -0.180 & 0.132 & & & & & \\
\hline 4. Board size & 7.794 & 4.909 & 1 & 17 & $0.277 *$ & $0.419 * *$ & 0.240 & & & & \\
\hline $\begin{array}{l}\text { 5. Family women on the } \\
\text { board }\end{array}$ & 0.071 & 0.147 & 0 & 1 & -0.081 & -0.237 & 0.072 & -0.204 & & & \\
\hline $\begin{array}{l}\text { 6. Non-family women on } \\
\text { the board }\end{array}$ & 0.151 & 0.154 & 0 & 0.667 & 0.036 & 0.219 & 0.054 & $0.449 * *$ & -0.101 & & \\
\hline 7. CSR engagement & 0.194 & 0.235 & 0 & 0.907 & -0.129 & $0.601 * *$ & -0.090 & $0.314 *$ & -0.086 & $0.440 * *$ & \\
\hline
\end{tabular}

\footnotetext{
${ }^{2}$ https://www.hofstede-insights.com
} 
Notes: $\mathrm{N}=63 ; * \mathrm{p}<0.05 ; * * \mathrm{p}<0.01$

Table 3

Regression analysis. The effects of female family and non-family directors on CSR and philanthropic engagement.

\begin{tabular}{lcccc}
\hline & \multicolumn{2}{c}{ CSR engagement } & \multicolumn{2}{c}{ Philanthropic engagement } \\
Variables & Step 1 & Step 2 & Step 1 & Step 2 \\
\hline Power distance & $-0.005^{*}$ & $-0.004 \dagger$ & $-0.00780^{*}$ & $-0.008^{*}$ \\
& $(0.0024)$ & $(0.0024)$ & $(0.00363)$ & $(0.00317)$ \\
Firm size & $0.084^{* * *}$ & $0.086^{* * *}$ & $0.0804^{* *}$ & $0.086^{* * *}$ \\
& $(0.0168)$ & $(0.0201)$ & $(0.0256)$ & $(0.0237)$ \\
Past performance & $-0.167^{*}$ & $-0.157^{*}$ & -0.144 & -0.156 \\
& $(0.0690)$ & $(0.0654)$ & $(0.105)$ & $(0.105)$ \\
Board size & $0.010 \dagger$ & 0.003 & 0.0112 & 0.011 \\
& $(0.0056)$ & $(0.0055)$ & $(0.00859)$ & $(0.00957)$ \\
Family women on the board & & 0.150 & & $0.290 \dagger$ \\
Non-family women on the board & & $(0.0896)$ & & $(0.169)$ \\
& & $0.483^{* *}$ & & 0.081 \\
Constant & & $(0.176)$ & & $(0.207)$ \\
& & & & $-1.002 \dagger$ \\
Observations & & $-1.417^{* *}$ & -0.856 & $(0.512)$ \\
R-squared & $(0.363)$ & $(0.468)$ & $(0.553)$ & 63 \\
Adjusted R-squared & & & & 0.286 \\
F & 63 & 63 & 0.268 & 0.210 \\
\hline
\end{tabular}

Notes: Robust standard errors in parentheses; $* * * \mathrm{p}<0.001,{ }^{* *} \mathrm{p}<0.01,{ }^{*} \mathrm{p}<0.05, \dagger \mathrm{p}<0.1$

The first step shows that size, past performance, number of board members, and power distance are significant for CSR engagement, while only size and power distance are significant for philanthropic engagement. The second step in Model 1 reveals a positive relationship between non-family women on the board and CSR engagement $(b=0.483 ; \mathrm{p}<0.01)$. Conversely, there is no significant relationship between family women on the board and CSR engagement. In sum, we find support for H1 and state that female directors are beneficial for CSR engagement only if not members of the controlling family.

In contrast, in the second step of Model 2, the relationship of the independent variables with philanthropic engagement shows different results. Family women on the board are positively related with philanthropic engagement $(b=0.290 ; p<0.10)$, while there is no significant relationship between non-family women on the board with philanthropic engagement. Thus, our results support $\mathrm{H} 2$ 
suggesting that women on the board of directors are beneficial for philanthropy only if they are members of the controlling family.

We performed a number of robustness checks. To check the assumption of homoscedasticity, we conducted the Breusch-Pagan Lagrange Multiplier test (Breusch and Pagan, 1979). For all models, the high p-value suggests heteroscedasticity is not a concern. Moreover, we predicted the residuals and used the Shapiro-Wilk W-test for normal data (Royston, 1983), suggesting there are no problems of violating the assumptions of normality. Given the characteristics of the dependent variables that are continuous measures ranging from 0 to 1 , we adopted the Tobit regression for censored data (see, for instance, Brammer and Millington, 2006; Jizi et al., 2014). As Table 4 shows, the results are analogous to those found with the linear regression, thus suggesting that our analyses are robust.

Table 4

$\underline{\text { Robustness checks. Tobit regression analysis. }}$

\begin{tabular}{|c|c|c|c|c|}
\hline \multirow[b]{2}{*}{ Variables } & \multicolumn{2}{|c|}{ CSR engagement } & \multicolumn{2}{|c|}{ Philanthropic engagement } \\
\hline & Step 1 & Step 2 & Step 1 & Step 2 \\
\hline Power distance & $\begin{array}{c}-0.00594^{*} \\
(0.00270)\end{array}$ & $\begin{array}{c}-0.00484 \dagger \\
(0.00255)\end{array}$ & $\begin{array}{c}-0.00948^{* *} \\
(0.00350)\end{array}$ & $\begin{array}{l}-0.00940 * \\
(0.00360)\end{array}$ \\
\hline Firm size & $0.104 * * *$ & $0.105 * * *$ & $0.0927 * *$ & $0.0998 * *$ \\
\hline & $(0.0218)$ & $(0.0219)$ & $(0.0284)$ & $(0.0291)$ \\
\hline Past performance & $\begin{array}{l}-0.191 * \\
(0.0937)\end{array}$ & $\begin{array}{l}-0.179 * \\
(0.0852)\end{array}$ & $\begin{array}{l}-0.173 \\
(0.131)\end{array}$ & $\begin{array}{l}-0.194 \\
(0.130)\end{array}$ \\
\hline Board size & $\begin{array}{c}0.00823 \\
(0.00568)\end{array}$ & $\begin{array}{c}0.00157 \\
(0.00674)\end{array}$ & $\begin{array}{c}0.0101 \\
(0.0106)\end{array}$ & $\begin{array}{c}0.0118 \\
(0.0126)\end{array}$ \\
\hline Family women on the board & & $\begin{array}{c}0.179 \\
(0.101)\end{array}$ & & $\begin{array}{l}0.381 * \\
(0.188)\end{array}$ \\
\hline Non-family women on the board & & $\begin{array}{l}0.446^{*} \\
(0.204)\end{array}$ & & $\begin{array}{c}0.00970 \\
(0.289)\end{array}$ \\
\hline Constant & $\begin{array}{c}-1.664 * * \\
(0.489)\end{array}$ & $\begin{array}{c}-1.768 * * * \\
(0.490)\end{array}$ & $\begin{array}{l}-1.036 \dagger \\
(0.556)\end{array}$ & $\begin{array}{c}-1.221 * \\
(0.585)\end{array}$ \\
\hline Observations & 63 & 63 & 63 & 63 \\
\hline Schwarz Criterion & 15.064 & 16.298 & 74.537 & 80.979 \\
\hline Pseudo- $\mathrm{R}^{2}$ & 1.342 & 1.588 & 0.263 & 0.290 \\
\hline
\end{tabular}

Notes: Robust standard errors in parentheses; *** $\mathrm{p}<0.001, * * \mathrm{p}<0.01, * \mathrm{p}<0.05, \dagger \mathrm{p}<0.1$

Finally, we ran the Durbin-Wu-Hausman test (Davidson and MacKinnon, 1993), an augmented regression test that includes the residuals of each endogenous variable as a function of all exogenous variables in a regression of the original model. In all cases, the results suggest endogeneity is not an issue.

\section{Discussion}




\subsection{Types of female directors and corporate citizenship behavior}

In this study, we have investigated the relationship between women (family and non-family) on the board of directors and corporate citizenship behavior, examining both CSR and philanthropic engagement in family firms. In particular, we offer novel insights on the role of women in corporate citizenship behavior (e.g., Bear et al., 2010; Buil-Fabregà et al., 2017; del Mar Alonso-Almeida et al., 2015; Fernandez-Feijoo et al., 2014; Nadeem et al., 2017; Setó-Pamies, 2015; Webb, 2004). Women have a positive impact on CSR and philanthropy thanks to a leadership style that leverages dyadic relationships and a care-taking attitude toward stakeholders and the community in which the family firm is embedded (Peake et al., 2017). This is also the case in the fashion industry, where attention to the environmental impact of firm activities (De Brito et al., 2008) and reputation in the eyes of stakeholders (Joergens, 2006) are extremely relevant. Our findings offer a finer-grained analysis of the effect of women on family firm corporate citizenship behavior. On the one hand, with respect to CSR, this study shows that the influence of female directors is positive only when they are not family members. Nevertheless, the positive effect of women on firm engagement in social issues, as selfconstrual theory suggests, is supported when considering only the relationship between family women on the board of directors and philanthropic initiatives. This finding suggests that family members have a say on actions that have a potential effect on corporate reputation (Deephouse and Jaskiewicz, 2013), offering novel insights on the strategic role of family and non-family women. In addition, these contrasting findings show the importance of breaking down diversity, not focusing on gender, but on family and non-family membership, to further understand what affects corporate citizenship behavior in family firms. Indeed, focusing the investigation only on women allows further understanding corporate behaviors, in line with existing research (e.g., Mari et al., 2016)

The findings of this study advance the predictions of self-construal theory by explicitly taking into account female directors' membership of the family controlling the business to explore their sensitivity to additional constraints or levers that might affect their behavior (Cross and Madson, 1997). On the one hand, female directors who are not members of the controlling family can leverage their experience and networks to enhance the business reputation. Their attitude to building interpersonal relationships 
is more likely directed at implementing any social initiatives that have positive implications for both the business' reputation and their own operations. When hired in a leadership position in the family business, they ensure the economic, legal, and social impact of their decisions for the benefit of the business through CSR engagement. On the other hand, when considering philanthropy, the implications of interdependent self-construal are combined with the quest for building and maintaining a positive family reputation, thus leading female directors who are members of the controlling family to engage in such initiatives. Philanthropic initiatives are not aimed at strategically investing in business-related activities (usually along the supply chain, such as a green certification), but refer to donations to often unrelated stakeholders, increasing the visibility of the family and its members (Pan et al., 2018). The nurturing traits of women, which self-construal theory considers central to the way they relate to close others (Cross and Madson, 1997), are reflected in the family's reputational concerns, ultimately leading to positive philanthropic engagement.

\subsection{Implications for theory and practice}

This study contributes novel insights on the role of women in corporate governance, family business, and corporate citizenship behavior. First, we contribute to the corporate governance literature by showing that the beneficial effects of female directors on firm behavior (Terjesen et al., 2009) do not always unfold when considering the family firm as a governance archetype. In this specific context, it is important to take into account the family versus non-family membership of women. As such, our study points to the importance of family membership as a key contingency in determining the effect of female directors on firm behavior. We also contribute to family business studies, and particularly to the emerging stream of literature on women in family firms (Jimenez, 2009), by showing that the presence of family versus non-family women on the board of directors affects CSR and philanthropic engagement decisions, an under-researched topic in family business research (De Massis et al., 2012; Van Gils et al., 2014). Indeed, this study offers a more nuanced perspective of family firms' investments in CSR, since business reputation gains are particularly relevant for non-family women on the board of directors. Important to consider instead is what drives family versus non-family women on the board to steer CSR toward a sustainable supply chain, considering not only their orientation to stakeholders but mostly their 
potential impact on the family and the business. Last, our study on the antecedents of CSR and philanthropy enriches corporate citizenship literature, distinguishing the effects of family and nonfamily female directors. We introduce family membership as a relevant characteristic of female directors that may affect the way they establish social priorities, manage their stakeholders, develop CSR along the supply chain, and prompt philanthropic initiatives (O'Riordan and Fairbrass, 2008). In line with the debate contending that corporate citizenship behavior fosters the satisfaction of multiple stakeholder expectations (Pacheco et al., 2018), we show that women prioritizing business or family reputation determines the extent to which firms engage in corporate citizenship behavior, highlighting differences between engaging in CSR and philanthropic initiatives.

Moreover, the focus on family business offers an ideal setting to further contribute to self-construal theory, which can be enriched by taking into account cultural and organizational issues, such as directors' membership of the controlling family, to offer a more fine-grained analysis of interdependent self-construal on the cognitions, emotions, and motivations of female directors (Cross et al., 2011). Whether female directors engage in corporate citizenship behavior or not might depend not only on the interdependent nature of their self-construal (Peake et al., 2017), but also on their family membership that determines their focus on mostly the family's rather than the business' reputation.

These findings also have practical implications. Family firms are advised to consider that not only women have a strong effect on CSR and philanthropic initiatives, but that female family and non-family directors might place greater emphasis on respectively the family or the business reputation. Family firms, especially those operating in the fashion industry and other industries where social issues are particularly important, can benefit from this study's findings. They should consider that the family status of board members influences organizational practices, affecting the priorities of female family and non-family directors in responding to stakeholder claims. Another managerial implication relates to the professionalization of the family business, since our findings suggest that family firms willing to increase their CSR engagement rather than philanthropic engagement should strongly consider the possibility of appointing female non-family directors. In addition, the study also offers practical implications for sustainability. Corporate citizenship behavior cannot be only imposed or fostered topdown (e.g. GRI guidelines or ESG criteria), but CSR and philanthropic initiatives also depend on 
internal, family- and individual-level dimensions. Policy makers should note that the presence of women is not only an item on the checklist to comply with laws, but an antecedent that can have a significant impact on corporate citizenship behavior.

\section{Limitations and Future Research Directions}

This study provides empirical support for the hypothesized CSR and philanthropic engagement difference between female directors who are family members and those who are not. However, we acknowledge the limitations of our study, which represent the boundaries of our contribution but also provide opportunities for future research. In particular, the cross-sectional nature of our data does not allow arguing for causality, and future studies might investigate this issue with a longitudinal design. This is not a severe shortcoming, since the independent variables do not change in the short term, and offers new research directions aimed at considering the tenure of female directors (Ryan and Haslam, 2007) and the change in board positions as antecedents of variations in CSR and philanthropic engagement. In addition, we controlled for power distance as a possible cultural aspect affecting CSR and philanthropic engagement, but other aspects, such as organizational culture and values (e.g., Parada et al., 2010), as well as the importance given to firm philanthropy (e.g., Campopiano et al., 2014), could be considered in future research to better characterize family firms, the main traits of directors' style, and firm propensity to engage in CSR and philanthropy.

In this paper, we infer concepts that have not been directly measured, e.g. reputation and interdependent self-construal. Future research might measure and introduce these concepts in an integrative model. It would also be interesting to understand whether the interaction between female CEOs and female board directors affects CSR and philanthropic engagement in family firms, in the same way it would seem to affect financial performance (Amore et al., 2014). Concerning the role of female CEOs, although previous studies analyze the relationship between the presence of women in executive positions on performance (Nekhili et al., 2018), and on CSR or philanthropy (del Mar AlonsoAlmeida et al., 2015; Hudson and Miller, 2005; Pearson, 2007), in our sample - constituted of familycontrolled firms - there are only five female family CEOs and one female non-family CEO. While this does not allow examining the role of female CEOs, the fact that only six firms out of 63 have women 
serving as CEOs clearly indicates the magnitude of gender issues in family-controlled fashion firms. Future research might investigate the reason for this dearth of women appointed in leadership positions through a qualitative research design that can help shed light on this disparity. Different theoretical lenses can assist this research direction, such as motivational theories. Self-determination theory recently used in family business studies (Cooper and Peake, 2018; Jiang et al., 2018) can provide the foundations for more in-depth theorizing on why and how women contribute to family firm citizenship behavior.

In addition, it would be relevant to discuss the extent to which stereotypes play a role in the effect of female family directors and CEOs on decisions such as CSR and philanthropic engagement (Rodríguez-Ariza et al., 2017). In particular, future research might investigate the moderating effect of stereotype threat, i.e. the fear of being judged according to a negative stereotype (Roberson and Kulik, 2007). Indeed, women entrepreneurship research suggests that stereotype threat might affect the behavior, values, and actions of women, especially in the context of family firms (Greene et al., 2013; Jennings and Brush, 2013). Furthermore, we focus on a dataset of family firms to identify differences between female directors who are members of the controlling family and those who are not. We welcome future research endeavors aimed at examining the differences between family-controlled and non-family-controlled firms. If employing a more heterogeneous dataset of firms, such studies would help further improve our understanding of the mechanisms behind the effect of female directors and reputational concerns on corporate citizenship. Finally, our study focuses on one industry, i.e. fashion. However, recent research emphasizes that the industrial sector shapes organizational phenomena, thus calling for investigating the industry-specific determinants of firm behavior (De Massis et al., 2018). Future research might investigate whether similar effects are found in other sectors, also relying on cross-industry studies, and whether environmental factors, such as dynamism (Chirico and Bau, 2014), turbulence (Naldi et al., 2013), or technology intensity (Muñoz-Bullón and Sanchez-Bueno, 2011), moderate the main relationships investigated in our study. In so doing, and as prior studies indicate (e.g., Campopiano and De Massis, 2015), scholars should consider that the definition and operationalization of CSR and philanthropy depend on the industry under investigation. Furthermore 
and relatedly, it would be relevant to consider the impact of CSR and philanthropic initiatives in specific industries in developing and emerging economies (Jia et al., 2018).

\section{Conclusions}

In sum, this study integrates arguments from self-construal theory, women in family business literature, and corporate reputation to examine the effect of female directors in family firms on corporate citizenship behavior, which we have examined by distinguishing between CSR and philanthropic engagement. Drawing on the population of 63 family-controlled firms in the global ranking of the top100 fashion firms, we find support for our hypotheses: women directors are beneficial for CSR in family firms only if they are not members of the controlling family, whereas they foster philanthropic engagement only if they are members of the controlling family. Our theory and empirics show that while a quest for family reputation spurs female family directors to engage in philanthropy, business reputation drives female non-family directors to engage in CSR. Even when resolving the dilemma as family women who "face the ambivalence involved in making the switch from a life of shrimp salad and tennis to the pursuit of a business career" (Lyman et al., 1985, p. 49), the effect of their decisions on the family rather than on the business system affects their behavior as directors of family firms. Given the many contingencies that might affect the corporate citizenship behavior of family firms, and the effect of female directors on such behavior, we have only started scratching the surface of issues that need to be further investigated. Thus, we will consider our efforts successful if we have encouraged other scholars to work at the intersection of corporate governance, family business, and corporate engagement on social responsibility and philanthropy.

\section{References}

Amore, M.D., Garofalo, O., Minichilli, A., 2014. Gender interactions within the family firm. Manag. Sci. 60, 1083-1097. https://doi.org/10.1287/mnsc.2013.1824

Bammens, Y., Voordeckers, W., Van Gils, A., 2011. Boards of directors in family businesses: A literature review and research agenda. Int. J. Manag. Rev. 13, 134-152. https://doi.org/10.1111/j.1468-2370.2010.00289.x

Battaglia, M., Testa, F., Bianchi, L., Iraldo, F., Frey, M., 2014. Corporate social responsibility and competitiveness within SMEs of the fashion industry: Evidence from Italy and France. Sustainability 6, 872-893. https://doi.org/10.3390/su6020872 
Baumann-Pauly, D., Wickert, C., Spence, L.J., Scherer, A.G., 2013. Organizing corporate social responsibility in small and large firms: Size matters. J. Bus. Ethics 115, 693-705. https://doi.org/10.1007/s10551-013-1827-7

Baumeister, R.F., Sommer, K.L., 1997. What do men want? Gender differences and two spheres of belongingness: Comment on Cross and Madson (1997). Psychol. Bull. 122, 38-44. https://doi.org/10.1037/0033-2909.122.1.38

Bear, S., Rahman, N., Post, C., 2010. The impact of board diversity and gender composition on corporate social responsibility and firm reputation. J. Bus. Ethics 97, 207-221. https://doi.org/10.1007/s10551-010-0505-2

Bianco, M., Ciavarella, A., Signoretti, R., 2015. Women on corporate boards in Italy: The role of family connections. Corp. Gov.: Int. Rev. 23, 129-144. https://doi.org/10.1111/corg.12097

Bingham, J.B., Dyer, W.G., Smith, I., Adams, G.L., 2011. A stakeholder identity orientation approach to corporate social performance in family firms. J. Bus. Ethics 99, 565-585. https://doi.org/10.1007/s10551-010-0669-9

Block, J.H., Wagner, M., 2014. The effect of family ownership on different dimensions of corporate social responsibility: Evidence from large US firms. Bus. Strategy Environ. 23, 475-492. https://doi.org/10.1002/bse.1798

Brammer, S., Millington, A., 2006. Firm size, organizational visibility and corporate philanthropy: An empirical analysis. Bus. Ethics: Eur. Rev. 15, 6-18. https://doi/abs/10.1111/j.14678608.2006.00424.x

Brammer, S., Millington, A., 2008. Does it pay to be different? An analysis of the relationship between corporate social and financial performance. Strateg. Manag. J. 29, 1325-1343. https://doi/abs/10.1002/smj.714

Breusch, T.S., Pagan, A.R., 1979. A simple test for heteroscedasticity and random coefficient variation. Econometrica 47, 1287-1294. jstor.org/stable/1911963

Buil-Fabregà, M., del Mar Alonso-Almeida, M., Bagur-Femenías, L., 2017. Individual dynamic managerial capabilities: Influence over environmental and social commitment under a gender perspective. J. Clean. Prod. 151, 371-379. https://doi.org/10.1016/j.jclepro.2017.03.081

Burgess, Z., Tharenou, P., 2002. Women board directors: Characteristics of the few. J. Bus. Ethics 37, 39-49. https://doi.org/10.1023/A:1014726001155

Campopiano, G., De Massis, A., 2015. Corporate social responsibility reporting: A content analysis in family and non-family firms. J. Bus. Ethics 129, 511-534. https://doi.org/10.1007/s10551-0142174-z

Campopiano, G., De Massis, A., Chirico, F., 2014. Firm philanthropy in small-and medium-sized family firms: The effects of family involvement in ownership and management. Fam. Bus. Rev. 27, 244-258. https://doi.org/10.1177/0894486514538450

Campopiano, G., De Massis, A., Rinaldi, F.R., Sciascia, S., 2017. Women's involvement in family firms: Progress and challenges for future research. J. Fam. Bus. Strategy 8, 200-212. https://doi.org/10.1016/j.jfbs.2017.09.001

Carroll, A.B., 1991. The pyramid of corporate social responsibility: Toward the moral management of organizational stakeholders. Bus. Horizons 34, 39-48. https://doi.org/10.1016/00076813(91)90005-G

Cascino, S., Pugliese, A., Mussolino, D., Sansone, C., 2010. The influence of family ownership on the quality of accounting information. Fam. Bus. Rev. 23, 246-265. https://doi.org/10.1177/0894486510374302

Chirico, F., Bau, M., 2014. Is the family an "asset" or "liability" for firm performance? The moderating role of environmental dynamism. J. Small Bus. Manag. 52, 210-225. https://doi.org/10.1111/jsbm.12095

Chrisman, J.J., Chua, J.H., Sharma, P., 2005. Trends and directions in the development of a strategic management theory of the family firm. Entrepren. Theory Pract. 29, 555-575. https://doi.org/10.1111/j.1540-6520.2005.00098.x 
Chua, J.H., Chrisman, J.J., Sharma, P., 1999. Defining the family business by behavior. Entrepren. Theory Pract.23, 19-39. https://doi.org/10.1177/104225879902300402

Ciliberti, F., Pontrandolfo, P., Scozzi, B., 2008. Investigating corporate social responsibility in supply chains: A SME perspective. J. Clean. Prod. 16, 1579-1588. https://doi.org/10.1016/j.jclepro.2008.04.016

Cochran, P.L., Wood, R.A., 1984. Corporate social responsibility and financial performance. Acad. Manag. J. 27, 42-56. https://doi.org/10.5465/255956

Cooper, D., Peake, W.O., 2018. Commentary: Family member well-being in the kinship enterprise: A self-determination perspective. Entrepren. Theory Pract. 42, 340-345. https://doi.org/10.1177/1042258717749238

Craig, J., Dibrell, C., 2006. The natural environment, innovation, and firm performance: A comparative study. Fam. Bus. Rev. 19, 275-288. https://doi.org/10.1111/j.1741-6248.2006.00075.x

Cross, S.E., Bacon, P.L., Morris, M.L., 2000. The relational-interdependent self-construal and relationships. J. Pers. Soc. Psychol. 78, 791-808. https://doi.org/10.1037/0022-3514.78.4.791

Cross, S.E., Hardin, E.E., Gercek-Swing, B., 2011. The what, how, why, and where of self-construal. Pers. Soc. Psychol. Rev. 15, 142-179. https://doi.org/10.1177/1088868310373752

Cross, S.E., Madson, L., 1997. Models of the self: self-construals and gender. Psychol. Bull. 122, 5-37. https://doi.org/10.1037/0033-2909.122.1.5

Cruz, C., Justo, R., De Castro, J.O., 2012. Does family employment enhance MSEs performance? Integrating socioemotional wealth and family embeddedness perspectives. J. Bus. Ventur. 27, 6276. https://doi.org/10.1016/j.jbusvent.2010.07.002

Cruz, C., Larraza-Kintana, M., Garcés-Galdeano, L., Berrone, P., 2014. Are family firms really more socially responsible? Entrepren. Theory Pract.38, 1295-1316. https://doi.org/10.1111/etap.12125

Cuadrado-Ballesteros, B., Rodríguez-Ariza, L., García-Sánchez, I.-M., 2015. The role of independent directors at family firms in relation to corporate social responsibility disclosures. Int. Bus. Rev. 24, 890-901. https://doi.org/10.1016/j.ibusrev.2015.04.002

Davidson, R., MacKinnon, J.G., 1993. Estimation and inference in econometrics. Oxford University Press, New York.

De Angelis, M., Adıg̈̈zel, F., Amatulli, C., 2017. The role of design similarity in consumers' evaluation of new green products: An investigation of luxury fashion brands. J. Clean. Prod. 141, 1515-1527. https://doi.org/10.1016/j.jclepro.2016.09.230

De Brito, M.P., Carbone, V., Blanquart, C.M., 2008. Toward a sustainable fashion retail supply chain in Europe: Organisation and performance. Int. J. Prod. Econ. 114, 534-553. https://doi.org/10.1016/j.ijpe.2007.06.012

Deephouse, D.L., Jaskiewicz, P., 2013. Do family firms have better reputations than non-family firms? An integration of socioemotional wealth and social identity theories. J. Manag. Stud. 50, 337-360. https://doi.org/10.1111/joms.12015

del Mar Alonso-Almeida, M., Perramon, J., Bagur, L., 2015. Women managers and corporate social responsibility (CSR) in Spain: Perceptions and drivers. Women's Stud. Int. Forum 50, 47-56. https://doi.org/10.1016/j.wsif.2015.02.007

De Massis, A., Kotlar, J., Wright, M., Kellermanns, F.W., 2018. Sector-based entrepreneurial capabilities and the promise of sector studies in entrepreneurship. Entrepren. Theory Pract.42, 3-23. https://doi.org/10.1177/1042258717740548

De Massis, A., Sharma, P., Chua, J.H., Chrisman, J.J., 2012. Family business studies: An annotated bibliography. Edward Elgar Publishing, Cheltenham Glos, UK.

Déniz Déniz, M.D.L.C., Cabrera Suárez, M.K., 2005. Corporate social responsibility and family business in Spain. J. Bus. Ethics 56, 27-41. https://doi.org/10.1007/s10551-004-3237-3

Dissanayake, D., Tilt, C., Xydias-Lobo, M., 2016. Sustainability reporting by publicly listed companies in Sri Lanka. J. Clean. Prod. 129, 169-182. https://doi.org/10.1016/j.jclepro.2016.04.086 
Dou, J., Zhang, Z., Su, E., 2014. Does family involvement make firms donate more? Empirical evidence from Chinese private firms. Fam. Bus. Rev. 27, 259-274. https://doi.org/10.1177/0894486514538449

Dyer, W.G., Whetten, D.A., 2006. Family firms and social responsibility: Preliminary evidence from the S\&P 500. Entrepren. Theory Pract.30, 785-802. https://doi.org/10.1111/j.15406520.2006.00151.x

Eberhardt-Toth, E., 2017. Who should be on a board corporate social responsibility committee? J. Clean. Prod. 140, 1926-1935. https://doi.org/10.1016/j.jclepro.2016.08.127

Elkington, J., 2006. Governance for sustainability. Corp. Gov.: Int. Rev. 14, 522-529. https://doi.org/10.1111/j.1467-8683.2006.00527.x

Epstein, E.M., 1987. The corporate social policy process: Beyond business ethics, corporate social responsibility, and corporate social responsiveness. Calif. Manag. Rev. 29, 99-114. https://doi.org/10.2307/41165254

European Commission, 2001. Promoting a European Framework for Corporate Social Responsibility: Green Paper. Office for Official Publications of the European Communities. Available at http://ec.europa.eu/transparency/regdoc/rep/1/2001/EN/1-2001-366-EN-1-0.Pdf

Feliu, N., Botero, I.C., 2016. Philanthropy in family enterprises: A review of literature. Fam. Bus. Rev. 29, 121-141. https://doi.org/10.1177/0894486515610962

Fernandez-Feijoo, B., Romero, S., Ruiz-Blanco, S., 2014. Women on boards: Do they affect sustainability reporting? Corp. Soc. Responsib. Environ. Manag. 21, 351-364. https://doi.org/10.1002/csr.1329

Forbes, 2015. Making climate change fashionable: The garment industry takes on global warming. Available at https://www.forbes.com/sites/jamesconca/2015/12/03/making-climate-changefashionable-the-garment-industry-takes-on-global-warming/\#3031cd0579e4.

Frias-Aceituno, J.V., Rodriguez-Ariza, L., Garcia-Sanchez, I., 2013. The role of the board in the dissemination of integrated corporate social reporting. Corp. Soc. Responsib. Environ. Manag. 20, 219-233. https://doi.org/10.1002/csr.1294

Frishkoff, P.A., Brown, B.M., 1993. Women on the move in family business. Bus. Horizons 36, 66-70. https://doi.org/10.1016/S0007-6813(05)80040-0

Galbreath, J., 2011. Are there gender-related influences on corporate sustainability? A study of women on boards of directors. J. Manag. Organ. 17, 17-38. https://doi.org/10.1017/S1833367200001693

Gardberg, N.A., Fombrun, C.J., 2006. Corporate citizenship: Creating intangible assets across institutional environments. Acad. Manag. Rev. 31, 329-346. https://doi.org/10.5465/amr.2006.20208684

Godos-Díez, J.-L., Fernández-Gago, R., Martínez-Campillo, A., 2011. How important are CEOs to CSR practices? An analysis of the mediating effect of the perceived role of ethics and social responsibility. J. Bus. Ethics 98, 531-548. https://doi.org/10.1007/s10551-010-0609-8

Gómez-Mejía, L.R., Haynes, K.T., Núñez-Nickel, M., Jacobson, K.J., Moyano-Fuentes, J., 2007. Socioemotional wealth and business risks in family-controlled firms: Evidence from Spanish olive oil mills. Adm. Sci. Q. 52, 106-137. https://doi.org/10.2189/asqu.52.1.106

Graves, C., Thomas, J., 2006. Internationalization of Australian family businesses: A managerial capabilities perspective. Fam. Bus. Rev. 19, 207-224. https://doi.org/10.1111/j.17416248.2006.00066.x

Greene, F.J., Han, L., Marlow, S., 2013. Like mother, like daughter? Analyzing maternal influences upon women's entrepreneurial propensity. Entrepren. Theory Pract.37, 687-711. https://doi.org/10.1111/j.1540-6520.2011.00484.x

Greve, A., Salaff, J.W., 2003. Social networks and entrepreneurship. Entrepren. Theory Pract. 28, 122. https://doi.org/10.1111/1540-8520.00029

Hamilton, L., 2012. Statistics with Stata, 12th ed. Cengage Learning, Belmont, CA. 
Hernández-Linares, R., Sarkar, S., Cobo, M.J., 2018. Inspecting the Achilles heel: A quantitative analysis of 50 years of family business definitions. Scientometrics 115, 929-951. https://doi.org/10.1007/s11192-018-2702-1

Huang, S.K., 2013. The impact of CEO characteristics on corporate sustainable development. Corp. Soc. Responsib. Environ. Manag. 20, 234-244. https://doi.org/10.1002/csr.1295

Hudson, S., Miller, G., 2005. Ethical orientation and awareness of tourism students. J. Bus. Ethics 62, 383-396. https://doi.org/10.1007/s10551-005-0850-8

Hutchins, M.J., Sutherland, J.W., 2008. An exploration of measures of social sustainability and their application to supply chain decisions. J. Clean. Prod. 16, 1688-1698. https://doi.org/10.1016/j.jclepro.2008.06.001

Ibrahim, N.A., Angelidis, J.P., 2011. Effect of board members' gender on corporate social responsiveness orientation. J. Appl. Bus. Res. 10, 35-40. https://doi.org/10.19030/jabr.v10i1.5961

Jamali, D., Safieddine, A.M., Rabbath, M., 2008. Corporate governance and corporate social responsibility synergies and interrelationships. Corp. Gov.: Int. Rev. 16, 443-459. https://doi.org/10.1111/j.1467-8683.2008.00702.x

Jennings, J.E., Brush, C.G., 2013. Research on women entrepreneurs: Challenges to (and from) the broader entrepreneurship literature? Acad. Manag. Ann. 7, 663-715. https://doi.org/10.1080/19416520.2013.782190

Jia, F., Zuluaga-Cardona, L., Bailey, A., Rueda, X., 2018. Sustainable supply chain management in developing countries: An analysis of the literature. J. Clean. Prod. 189, 263-278. https://doi.org/10.1016/j.jclepro.2018.03.248

Jiang, D.S., Kellermanns, F.W., Munyon, T.P., Morris, M.L., 2018. More than meets the eye: A review and future directions for the social psychology of socioemotional wealth. Fam. Bus. Rev. 31, 125157. https://doi.org/10.1177/0894486517736959

Jimenez, R.M., 2009. Research on women in family firms: Current status and future directions. Fam. Bus. Rev. 22, 53-64. https://doi.org/10.1177/0894486517736959

Jizi, M.I., Salama, A., Dixon, R., Stratling, R., 2014. Corporate governance and corporate social responsibility disclosure: Evidence from the US banking sector. J. Bus. Ethics 125, 601-615. https://doi.org/10.1007/s10551-013-1929-2

Jo, H., Harjoto, M.A., 2012. The causal effect of corporate governance on corporate social responsibility. J. Bus. Ethics 106, 53-72. https://doi.org/10.1007/s10551-011-1052-1

Joergens, C., 2006. Ethical fashion: Myth or future trend? J. Fash. Mark. Manag.: Int. J. 10, 360-371. https://doi.org/10.1108/13612020610679321

Kotlar, J., Signori, A., De Massis, A., Vismara, S., 2017. Financial wealth, socioemotional wealth and IPO underpricing in family firms: A two-stage gamble model. Acad. Manag. J. 61. https://doi.org/10.5465/amj.2016.0256

Kozlowski, A., Bardecki, M., Searcy, C., 2012. Environmental impacts in the fashion industry. J. Corp. Citizsh. 45, 16-36. www.jstor.org/stable/jcorpciti.45.17

Labelle, R., Hafsi, T., Francoeur, C., Ben Amar, W., 2018. Family firms' corporate social performance: A calculated quest for socioemotional wealth. J. Bus. Ethics 148, 511-525. https://doi.org/10.1007/s10551-015-2982-9

Laguir, I., Laguir, L., Elbaz, J., 2016. Are family small- and medium-sized enterprises more socially responsible than nonfamily small- and medium-sized enterprises? Corp. Soc. Responsib. Environ. Manag. 23, 386-398. https://doi.org/10.1002/csr.1384

La Porta, R., López De Silanes, F., Shleifer, A., 1999. Corporate ownership around the world. J. Finance 54, 471-517. https://doi.org/10.1111/0022-1082.00115

Litz, R.A., Stewart, A.C., 2000. Charity begins at home: Family firms and patterns of community involvement. Nonprofit Volunt. Sect. Q. 29, 131-148. https://doi.org/10.1177/0899764000291008

Liu, X., Gao, X., 2016. A survey analysis of low carbon technology diffusion in China's iron \& steel industry. J. Clean. Prod. 129, 88-101. https://doi.org/10.1016/j.jclepro.2016.04.115 
Loorbach, D., Wijsman, K., 2013. Business transition management: Exploring a new role for business in sustainability transitions. J. Clean. Prod. 45, 20-28. https://doi.org/10.1016/j.jclepro.2012.11.002

Lungeanu, R., Ward, J.L., 2012. A governance-based typology of family foundations: The effect of generation stage and governance structure on family philanthropic activities. Fam. Bus. Rev. 25, 409-424. https://doi.org/10.1177/0894486512444603

Lyman, A., Salganicoff, M., Hollander, B., 1985. Women in family business: An untapped resource. SAM Adv. Manag. J. 50, 46-49.

Mari, M., Poggesi, S., De Vita, L., 2016. Family embeddedness and business performance: Evidences from women-owned firms. Manag. Decis. 54, 476-500. https://doi.org/10.1108/MD-07-2014-0453

Markus, H.R., Kitayama, S., 1991. Culture and the self: Implications for cognition, emotion, and motivation. Psychol. Rev.98, 224-253. https://doi.org/10.1037/0033-295X.98.2.224

Marques, P., Presas, P., Simon, A., 2014. The heterogeneity of family firms in CSR engagement: The role of values. Fam. Bus. Rev. 27, 206-227. https://doi.org/10.1177/0894486514539004

Martínez-Ferrero, J., Rodríguez-Ariza, L., García-Sánchez, I.-M., 2016. Corporate social responsibility as an entrenchment strategy, with a focus on the implications of family ownership. J. Clean. Prod. 135, 760-770. https://doi.org/10.1016/j.jclepro.2016.06.133

Miller, D., Le Breton-Miller, I., Lester, R.H., Cannella Jr, A.A., 2007. Are family firms really superior performers? J. Corp. Finance 13, 829-858. https://doi.org/10.1016/j.jcorpfin.2007.03.004

Moretto, A., Macchion, L., Lion, A., Caniato, F., Danese, P., Vinelli, A., 2018. Designing a roadmap toward a sustainable supply chain: A focus on the fashion industry. J. Clean. Prod. 193, 169-184. https://doi.org/10.1016/j.jclepro.2018.04.273

Muñoz-Bullón, F., Sanchez-Bueno, M.J., 2011. The impact of family involvement on the R\&D intensity of publicly traded firms. Fam. Bus. Rev. 24, 62-70. https://doi.org/10.1177/0894486510396870

Nadeem, M., Zaman, R., Saleem, I., 2017. Boardroom gender diversity and corporate sustainability practices: Evidence from Australian Securities Exchange listed firms. J. Clean. Prod. 149, 874-885. https://doi.org/10.1016/j.jclepro.2017.02.141

Naldi, L., Cennamo, C., Corbetta, G., Gomez-Mejia, L., 2013. Preserving socioemotional wealth in family firms: Asset or liability? The moderating role of business context. Entrepren. Theory Pract.37, 1341-1360. https://doi.org/10.1111/etap.12069

Nekhili, M., Chakroun, H., Chtioui, T., 2018. Women's leadership and firm performance: Family versus nonfamily firms. J. Bus. Ethics 153, 291-316. https://doi.org/10.1007/s10551-016-3340-2

Nelson, T., Constantinidis, C., 2017. Sex and gender in family business succession research: A review and forward agenda from a social construction perspective. Fam. Bus. Rev. 30, 219-241. https://doi.org/10.1177/0894486517715390

O'Riordan, L., Fairbrass, J., 2008. Corporate social responsibility (CSR): Models and theories in stakeholder dialogue. J. Bus. Ethics 83, 745-758. https://doi.org/10.1007/s10551-008-9662-y

Pacheco, L.M., Alves, M.F.R., Krüger, C., de Arruda Lourenção, M.T., Caldana, A.C.F., 2018. Are we all green? Understanding the microfoundations of corporate citizenship. J. Clean. Prod. 195, 552561. https://doi.org/10.1016/j.jclepro.2018.05.134

Pan, Y., Weng, R., Xu, N., Chan, K.C., 2018. The role of corporate philanthropy in family firm succession: A social outreach perspective. J. Bank. Finance 88, 423-441. https://doi.org/10.1016/j.jbankfin.2018.01.011

Parada, M.J., Nordqvist, M., Gimeno, A., 2010. Institutionalizing the family business: The role of professional associations in fostering a change of values. Fam. Bus. Rev. 23, 355-372. https://doi.org/10.1177/0894486510381756

Payne, G.T., Brigham, K.H., Broberg, J.C., Moss, T.W., Short, J.C., 2011. Organizational virtue orientation and family firms. Bus. Ethics Q. 21, 257-285. https://doi.org/10.5840/beq201121216

Peake, W.O., Cooper, D., Fitzgerald, M.A., Muske, G., 2017. Family business participation in community social responsibility: The moderating effect of gender. J. Bus. Ethics 142, 325-343. https://doi.org/10.1007/s10551-015-2716-z 
Pearson, R., 2007. Beyond women workers: Gendering CSR. Third World Q. 28, 731-749. https://doi.org/10.1080/01436590701336622

Peng, Y.-S., Dashdeleg, A.-U., Chih, H.L., 2014. Culture and firm's CSR engagement: A cross-nation study. J. Mark. Manag. 5, 38-49.

Porter, M.E., Kramer, M.R., 2002. The competitive advantage of corporate philanthropy. Harv. Bus. Rev. 80, 56-68. Available at http://www.expert2business.com/itson/Porter\%20HBR\%20Corporate\%20philantropy.pdf

Poza, E.J., Messer, T., 2001. Spousal leadership and continuity in the family firm. Fam. Bus. Rev. 14, 25-36. https://doi.org/10.1111/j.1741-6248.2001.00025.x

Ringov, D., Zollo, M., 2007. The impact of national culture on corporate social performance. Corp. Gov.: Int. J. Bus. Soc. 7, 476-485. https://doi.org/10.1108/14720700710820551

Ritala, P., Huotari, P., Bocken, N., Albareda, L., Puumalainen, K., 2018. Sustainable business model adoption among S\&P 500 firms: A longitudinal content analysis study. J. Clean. Prod. 170, 216226. https://doi.org/10.1016/j.jclepro.2017.09.159

Roberson, L., Kulik, C.T., 2007. Stereotype threat at work. Acad. Manag. Perspect. 21, 24-40. https://doi.org/10.5465/amp.2007.25356510

Robinson, S., Stubberud, H.A., 2012. All in the family: Entrepreneurship as a family tradition. Int. J. Entrepren.16, 19-29. Available at http://jeffreyrobinsonphd.com/wpcontent/uploads/2017/06/WholeIssue-ijevol16si12012-2.pdf\#page $=25$

Rodríguez-Ariza, L., Cuadrado-Ballesteros, B., Martínez-Ferrero, J., García-Sánchez, I.M., 2017. The role of female directors in promoting CSR practices: An international comparison between family and non-family businesses. Bus. Ethics: Eur. Rev.26, 162-174. https://doi.org/10.1111/beer.12140

Royston, J.P., 1983. Some techniques for assessing multivariate normality based on the Shapiro-Wilk W. Appl. Stat. 32, 121-133. /iwww.jstor.org/stable/2347291

Rubino, F.E., Tenuta, P., Cambrea, D.R., 2017. Board characteristics effects on performance in family and non-family business: A multi-theoretical approach. J. Manag. Gov. 21, 623-658. https://doi.org/10.1007/s10997-016-9363-3

Ryan, M.K., Haslam, S.A., 2007. The glass cliff: Exploring the dynamics surrounding the appointment of women to precarious leadership positions. Acad. Manag. Rev. 32, 549-572. https://doi.org/10.5465/amr.2007.24351856

Samara, G., Jamali, D., Sierra, V., Parada, M.J., 2018. Who are the best performers? The environmental social performance of family firms. J. Fam. Bus. Strategy 9, 33-43. https://doi.org/10.1016/j.jfbs.2017.11.004

Schwartz, M.S., Carroll, A.B., 2003. Corporate social responsibility: A three-domain approach. Bus. Ethics Q. 13, 503-530. https://doi.org/10.5840/beq200313435

Sciascia, S., Mazzola, P., Astrachan, J.H., Pieper, T.M., 2013. Family involvement in the board of directors: Effects on sales internationalization. J. Small Bus. Manag. 51, 83-99. https://doi.org/10.1111/j.1540-627X.2012.00373.x

Seaman, C., 2017. Turning point: Factoring the family into corporate citizenship. J. Corp. Citizsh. 65, 6-11. https://doi.org/10.9774/GLEAF.4700.2017.ma.00003

Seierstad, C., Warner-Søderholm, G., Torchia, M., Huse, M., 2017. Increasing the number of women on boards: The role of actors and processes. J. Bus. Ethics 141, 289-315. https://doi.org/10.1007/s10551-015-2715-0

Setó-Pamies, D., 2015. The relationship between women directors and corporate social responsibility. Corp. Soc. Responsib. Environ. Manag. 22, 334-345. https://doi.org/10.1002/csr.1349

Seuring, S., Gold, S., 2013. Sustainability management beyond corporate boundaries: From stakeholders to performance. J. Clean. Prod. 56, 1-6. https://doi.org/10.1016/j.jclepro.2012.11.033

Sharma, P., Sharma, S., 2011. Drivers of proactive environmental strategy in family firms. Bus. Ethics Q. 21,309-334. https://doi.org/10.5840/beq201121218 
Spence, L., Bourlakis, M., 2009. The evolution from corporate social responsibility to supply chain responsibility: The case of Waitrose. Supply Chain Manag.: Int. J. 14, 291-302. https://doi.org/10.1108/13598540910970126

Statista, 2013. Retail sales of the global apparel market. www.statista.com/statistics/732546/globalapparel-market-retail-sales-value/.

Terjesen, S., Couto Barbosa, E., Francisco Morais, P., 2016. Does the presence of independent and female directors impact firm performance? A multi-country study of board diversity. J. Manag. Gov. 20, 447-483. https://doi.org/10.1007/s10997-014-9307-8

Terjesen, S., Sealy, R., Singh, V., 2009. Women directors on corporate boards: A review and research agenda. Corp. Gov.: Int. Rev. 17, 320-337. https://doi.org/10.1111/j.1467-8683.2009.00742.x

The Guardian, 2015. Two years after Rana Plaza, have conditions improved in Bangladesh's factories? https://www.theguardian.com/sustainable-business/2015/apr/24/bangladesh-factories-buildingcollapse-garment-dhaka-rana-plaza-brands-hm-gap-workers-construction

The Guardian, 2016. Child labour in the fashion supply chain. https://labs.theguardian.com/unicefchild-labour

Van Gils, A., Dibrell, C., Neubaum, D.O., Craig, J.B., 2014. Social issues in the family enterprise. Fam. Bus. Rev. 27, 193-205. https://doi.org/10.1177/0894486514542398

Vermeulen, W.J., Witjes, S., 2016. On addressing the dual and embedded nature of business and the route toward corporate sustainability. J. Clean. Prod. 112, 2822-2832. https://doi.org/10.1016/j.jclepro.2015.09.132

Voordeckers, W., Van Gils, A., Van den Heuvel, J., 2007. Board composition in small and mediumsized family firms. J. Small Bus. Manag. 45, 137-156. https://doi.org/10.1111/j.1540627X.2007.00204.X

Waage, S.A., Geiser, K., Irwin, F., Weissman, A.B., Bertolucci, M.D., Fisk, P., Basile, G., Cowan, S., Cauley, H., McPherson, A., 2005. Fitting together the building blocks for sustainability: A revised model for integrating ecological, social, and financial factors into business decision-making. J. Clean. Prod. 13, 1145-1163. https://doi.org/10.1016/j.jclepro.2004.06.003

Wang, Z., Sarkis, J., 2017. Corporate social responsibility governance, outcomes, and financial performance. J. Clean. Prod. 162, 1607-1616. https://doi.org/10.1016/j.jclepro.2017.06.142

Webb, E., 2004. An examination of socially responsible firms' board structure. J. Manag. Gov. 8, 255277. https://doi.org/10.1007/s10997-004-1107-0

Williams, R.J., 2003. Women on corporate boards of directors and their influence on corporate philanthropy. J. Bus. Ethics 42, 1-10. https://doi.org/10.1023/A:1021626024014

Windsor, D., 2006. Corporate social responsibility: Three key approaches. J. Manag. Stud. 43, 93-114. https://doi.org/10.1111/j.1467-6486.2006.00584.x

World Health Organization, 2016. The public health impact of chemicals: Knowns and unknowns. http://apps.who.int/iris/bitstream/10665/206553/1/WHO_FWC_PHE_EPE_16.01_eng.pdf?ua=1.

Yawar, S.A., Seuring, S., 2018. The role of supplier development in managing social and societal issues in supply chains. J. Clean. Prod. 182, 227-237. https://doi.org/10.1016/j.jclepro.2018.01.234

Zellweger, T.M., Nason, R.S., 2008. A stakeholder perspective on family firm performance. Fam. Bus. Rev. 21, 203-216. https://doi.org/10.1177/08944865080210030103

Zhang, J.Q., Zhu, H., Ding, H.-B., 2013. Board composition and corporate social responsibility: An empirical investigation in the post Sarbanes-Oxley era. J. Bus. Ethics 114, 381-392. https://doi.org/10.1007/s10551-012-1352-0 